\title{
Correction to: Comparative de novo transcriptome analysis of barley varieties with different malting qualities
}

\author{
Leona Leišová-Svobodová ${ }^{1} \cdot V_{r a t i s l a v ~}$ Psota $^{2}$ · Štěpán Stočes ${ }^{3} \cdot$ Petr Vácha $^{3} \cdot$ Ladislav Kučera $^{1}$
}

(c) The Author(s) 2021

\section{Correction to: Functional \& Integrative Genomics (2020) 20:801-812 https://doi.org/10.1007/s10142-020-00750-z}

Originally, the number of funding project is incorrect. The correct number is presented below.

Funding This work was supported by the Czech Ministry of Agriculture, projects no: QK1910197 and MZe-RO0418.

Open Access This article is licensed under a Creative Commons Attribution 4.0 International License, which permits use, sharing, adaptation, distribution and reproduction in any medium or format, as long as you give appropriate credit to the original author(s) and the source, provide a link to the Creative Commons licence, and indicate if changes were made. The images or other third party material in this article are included in the article's Creative Commons licence, unless indicated otherwise in a credit line to the material. If material is not included in the article's Creative Commons licence and your intended use is not permitted by statutory regulation or exceeds the permitted use, you will need to obtain permission directly from the copyright holder. To view a copy of this licence, visit http://creativecommons.org/licenses/by/4.0/.

Publisher's note Springer Nature remains neutral with regard to jurisdictional claims in published maps and institutional affiliations.

The original article can be found online at https://doi.org/10.1007/ s10142-020-00750-z

Leona Leišová-Svobodová

leisova@vurv.cz

1 Crop Research Institute, Drnovská 507, 16106 Prague 6, Czech Republic

2 Research Institute of Brewing and Malting, Analytical Testing Laboratory - Malting Institute Brno, Mostecká 971/7, 61400 Brno, Czech Republic

3 SEQme s.r.o, Dlouhá 176 26301, Dobřríš, Czech Republic 